\title{
Seroprevalence of Helicobacter pylori Infection and Risk Factors among Asymptomatic Subjects in Delta State, Nigeria
}

\author{
Kingsley Ifeanyichukwu Omosor ${ }^{1}$, Omasan Herrienta Omosor ${ }^{1}$, Isaiah Nnana Ibeh ${ }^{2}$, \\ Babatunde Ishola Gabriel Adejumo ${ }^{2 *}$, Usman Itakure Abdulkadir ${ }^{3}$, Uchechukwu Dimkpa \\ Gregory Ashimedua Uchuno ${ }^{5}$, Ojo Moses 0ke ${ }^{6}$, Ramatu Lawal Abdulkadir ${ }^{7}$, \\ Musa Vaima Hamidu8, Alaba Michael Emmanuel ${ }^{9}$ \\ ${ }^{1}$ Shalom Diagnostic Medical Laboratory, Warri, Nigeria \\ ${ }^{2}$ Medical Laboratory Science Department, University of Benin, Benin City, Nigeria \\ ${ }^{3}$ Department of Medical Laboratory Science, College of Health Sciences and Technology, Markafi, Nigeria \\ ${ }^{4}$ Physiology Department, Nnewi Campus, Nnamdi Azikiwe University, Awka, Nigeria \\ ${ }^{5}$ External Quality Assurance Department, Medical Laboratory Science Council of Nigeria, Abuja, Nigeria \\ ${ }^{6}$ Department of Medical Laboratory Science, College of Health Sciences and Technology, Akure, Nigeria \\ ${ }^{7}$ Pathology Laboratory, 44, Nigerian Army Reference Hospital, Kaduna, Nigeria \\ ${ }^{8}$ Department of Medical Laboratory Science, College of Health Sciences and Technology, Maiduguri, Nigeria \\ ${ }^{9}$ Medical Laboratory Science Department, College of Health Sciences and Technology, Idah, Nigeria \\ Email: ^babatunde.adejumo@uniben.edu, ^bigadejumo@yahoo.com
}

How to cite this paper: Omosor, K.I., Omosor, O.H., Ibeh, I.N., Adejumo, B.I.G., Abdulkadir, U.I., Dimkpa, U., Uchuno, G.A., Oke, O.M., Abdulkadir, R.L., Hamidu, M.V., and Emmanuel, A.M. (2017) Seroprevalence of Helicobacter pylori Infection and Risk Factors among Asymptomatic Subjects in Delta State, Nigeria. Advances in Microbiology, 7, 641-652.

https://doi.org/10.4236/aim.2017.79050

Received: July 31, 2017

Accepted: September 3, 2017

Published: September 6, 2017

Copyright $\odot 2017$ by authors and Scientific Research Publishing Inc. This work is licensed under the Creative Commons Attribution International License (CC BY 4.0).

http://creativecommons.org/licenses/by/4.0/ (c) (i) Open Access

\begin{abstract}
Aim: The study aimed at evaluating the seroprevalence of $H$. pylori infection and its associated risk factors in a cross-section of asymptomatic adult population in Niger-Delta, Nigeria. Methodology: 408 apparently healthy volunteers, aged between 18 - 87 years were recruited for this study. Blood samples were collected from participants and analyzed for $H$. pylori antibody (IgG) qualitatively with Combo rapid kits and quantitatively with Accu-Bind ELISA Kits. Results: The overall prevalence of Helicobacter pylori colonization in 408 asymptomatic adults was $52.5 \%(\mathrm{n}=214)$ and $48.3 \%(\mathrm{n}=197)$ by qualitative (Combo rapid kits) and quantitative (Accu-Bind ELISA Kits) serological test methods respectively. $H$. pylori infection did not differ statistically between genders $(\mathrm{p}=0.962)$ and among age groups $(\mathrm{p}=0.185)$. In addition, multivariate logistic regression indicated that sex and age were not associated with risk of $H$. pylori. However, participants from Delta Central were at greater risk $(\mathrm{OR}=1.89 ; \mathrm{p}=0.014)$ of $H$. pylori infection compared with those from Delta South, but those from Delta North were not at greater risk of infection compared with those from Delta South $(\mathrm{p}=0.476)$. Conclusion: This study indicated an intermediate seroprevalence of $H$. pylori among asympto-
\end{abstract}


matic adults in Delta state, Nigeria. The prevalence of $H$. pylori infection was

linked to geographical regions but not with sex and age.

\section{Keywords}

Helicobacter pylori, Infection, Risk Factors, Delta State, Nigeria

\section{Introduction}

Helicobacter pylori, a Gram-negative bacterium that colonizes human gastric mucosa is one of the most common chronic infections which occurs worldwide, with $50 \%$ of the world's population estimated to be carriers of this organism [1] [2]. It is a major aetiological factor in chronic gastritis, peptic ulcer disease, gastric carcinoma, and gastric mucosal associated lymphoid tissue lymphoma [3] [4] [5] [6] [7]. The mode of transmission still remains unclear, but literature data suggest different modalities of transmission of the infection to include, personto-person, faeco-oral, oro-oral, gastro-oral and gastro-gastric transmissions [1] [8].

It has been established that Helicobacter pylori infection is commonly acquired during childhood [9] [10] [11], thus, any differences in prevalence of the infection within or among populations likely result from factors that were in effect during childhood. Previous reports show that age, race, living in rural area, overcrowding, socioeconomic status, poor sanitary conditions, mothers with lower educational level, poor diet and poor water supply are some of the important risk factors for transmission of H. pylori [1] [2] [12] [13] [14]. Prevalence of $H$. pylori infection in developing countries is higher compared with developed countries [15]. The decline in prevalence in developed countries is a reflection of higher socio-economic status and improved hygiene and sanitation and the active elimination of carriership via antimicrobial treatment [16] [17] [18]. In Nigeria, one of the developing countries, a high prevalence of $H$. pylori has been reported among adult populations with gastric and duodenal ulcers [19] [20] [21].

Diagnostic methods for Helicobacter pylori infection are classified as invasive and non-invasive. Invasive methods include culture, immunohistochemistry, rapid urease tests, or the polymerase chain reaction, which require upper gastrointestinal endoscopy for obtaining the diagnostic sample. On the other hand, non-invasive detection methods include the urea breath test, serological and stool antigen methods. It is not clear which method should be used as gold standard for the detection of $H$. pylori infection. However, of all the available tests, invasive tests are considered the most accurate. Serological methods are based on the detection of Helicobacter pylori specific antibodies in serum, saliva, or urine and are used for initial screening. The stool antigen test is particularly used when the urea breath test is not available. 
Previous studies on the seroprevalence of $H$. pylori have focused mainly on children and symptomatic adult populations. Limited studies exist on the prevalence of $H$. pylori among asymptomatic adult population in Nigeria. In the light of the rising incidents of gastritis and duodenal ulcers in Nigeria, as well as the importance of $H$. pylori infection in the pathogenesis of gastroduodenal diseases, there is therefore a need to re-appraise its seroprevalence rate in a cross-section of asymptomatic adult population. This study therefore was aimed at evaluating the seroprevalence of $H$. pylori infection and its associated risk factors in asymptomatic adult population in a Niger-Delta region of Nigeria. It is believed that the result of the present study will be helpful to plan a future large-scale population survey in different sex, age and socioeconomic groups.

\section{Methodology}

\subsection{Participants}

A total number of 408 apparently healthy volunteers, aged between 18 - 87 years were recruited for this study from the three senatorial districts of Delta state (Delta South, $\mathrm{n}=141$; Delta Central, $\mathrm{n}=128$ and Delta North, $\mathrm{n}=139$ ). A well-structured questionnaire was administered to every participant of this study to obtain their demographic information and health history. All volunteers with history of gastric ulcers were excluded from the study. Informed consents of participants were sought and obtained after explaining the purpose of the research. The Ethics committee of Ministry of Health, Delta State approved the study.

\subsection{Sample Collection}

Five $(5 \mathrm{~mL})$ of venous blood sample was collected from each participant and the serum separated immediately into sterile tubes and stored at a temperature of $2^{\circ} \mathrm{C}-8^{\circ} \mathrm{C}$ for up to 3 days prior to analysis. For a longer storage they were kept at $-20^{\circ} \mathrm{C}$ until analyzed for anti- Helicobacter pylori antibodies- IgG detection. All blood samples obtained from volunteers were screened qualitatively using aria Helicobacter pylori antibody combo rapid test kit (serum/plasma/whole blood) which is a sandwich lateral flow chromatographic immunoassay for the qualitative detection of antibodies against Helicobacter pylori in human serum/plasma or whole blood [22]. Serum/plasma samples were assayed quantitatively using the Accu-Bind ELISA Micro-wells for the detection of IgG Antibodies to H. pylori in human serum (system code, 1425-300; Monobind Inc., Lake Forest, CA 92630, USA).

Stool specimens were collected from the participants. Small piece of stool ( $\sim 5$ $\mathrm{mm}$ in diameter; $\sim 150 \mathrm{mg}$ ) was transferred into $1 \mathrm{ml}$ of Sample Treatment Solution in a test tube and mixed thoroughly. Stool samples obtained were screened qualitatively using aria Helicobacter pylori antigen rapid test kit (fecal specimen) which is a lateral flow chromatographic immunoassay for the qualitative detection of $H$. pylori antigen in human stool samples [23]. The stool samples were 
also assayed quantitatively using the stool antigen Accu-Diag ${ }^{\mathrm{TM}} H$. pylori Antigen ELISA Kit (Cat \#1506-11, USA).

All assay procedures were carried out according to manufacturer's instruction. All samples were analyzed at Shalom Medical Services, Warri-Delta State, Nigeria.

\subsection{Data Analysis}

Data was expressed as percentages for categorical variables. Comparative analyses to evaluate differences in $H$. pylori positivity between categorical variables were done using Chi-square test. The association between each potential risk factor and the outcome ( $H$. pylori status) was measured using logistic regression. Statistical significance was set at $\mathrm{p}<0.05$. All statistics were done using SPSS/ IBM statistical software (version 20).

\section{Results}

Table 1 shows the socio-demographic characteristics of the study population. Data indicated that majority (81.6\%) of the participants were aged between 18 39 years of age and followed by the age group, 40 - 59 years (13\%). Those aged $\geq 60$ years had the least percentage of the population (5.4\%). The mean age of the study population was $32.55 \pm 11.98$ years (range 18 - 87 years). Majority (70.6\%) of the study population were females, while the males constituted a smaller percentage $(29.4 \%)$ of the population. The participants were selected from Delta South (34.6\%), Delta North (34.1\%) and Delta Central (31.4\%) districts.

The overall prevalence of Helicobacter pylori colonization in 408 asymptomatics was $52.5 \%(\mathrm{n}=214)$ and $48.3 \%(\mathrm{n}=197)$ by qualitative (Combo rapid kits) and quantitative (Accu-Bind ELISA kits) serological test methods respectively (Figure 1).

The prevalence of $H$. pylori according to sex, age and geographical location of participants is summarized in Tables 2-4 respectively. Among the 408 subjects,

Table 1. Socio-demographic characteristics of the study population.

\begin{tabular}{ccc}
\hline CHARACTERISTICS & FREQUENCY & PERCENTAGE (\%) \\
\hline Age Group & 333 & 81.6 \\
$18-39$ yrs & 53 & 13.0 \\
$40-59$ yrs & 22 & 5.4 \\
$\geq 60$ yrs & & \\
Sex & 120 & 29.4 \\
Males & 288 & 70.6 \\
Females & & \\
Geographical Region & 128 & 31.4 \\
Delta Central & 139 & 34.1 \\
Delta North & 141 & 34.6 \\
Delta South & &
\end{tabular}




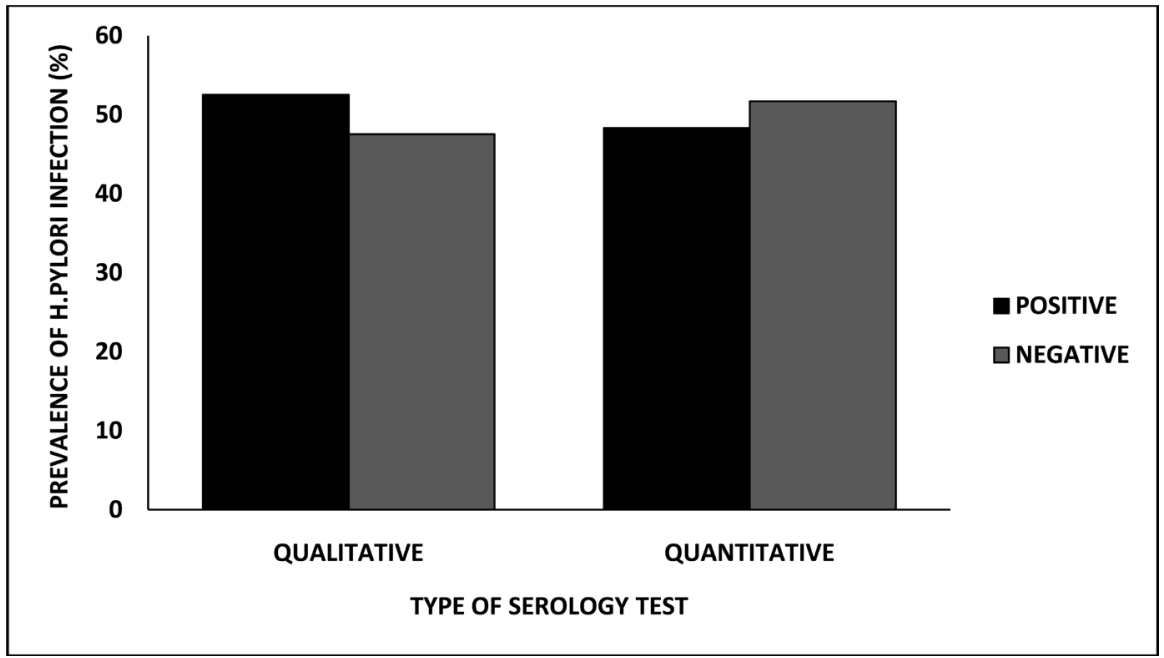

Figure 1 . The seroprevalence of $H$. pylori in the study population using two different test methods.

Table 2. The seroprevalence rate of $H$. pylori according to sex of subjects.

\begin{tabular}{cccc}
\hline Sex & Number of Subjects & Number of Positive Tests & Prevalence Rate (\%) \\
\hline Males & 120 & 66 & 55.0 \\
Females & 288 & 148 & 51.4 \\
Total & 408 & 214 & 52.5 \\
\hline
\end{tabular}

Table 3. The seroprevalence rate of $H$. pylori in different age groups.

\begin{tabular}{cccc}
\hline Age Groups & Number of Subjects & Number of Positive Tests & Prevalence Rate (\%) \\
\hline Young (18 - 39 yrs) & 333 & 176 & 52.9 \\
Middle-aged (40 - 59 yrs) & 53 & 24 & 45.3 \\
Elderly ( $\geq 60$ yrs) & 22 & 14 & 63.6 \\
Total & 408 & 214 & 52.5 \\
\hline
\end{tabular}

Table 4. The seroprevalence rate of $H$. pylori according to geographical regions of participants.

\begin{tabular}{cccc}
\hline Geographical Area & Number of Subjects & Number of Positive Tests & Prevalence Rate (\%) \\
\hline Delta Central & 128 & 79 & 61.7 \\
Delta North & 139 & 64 & 46.0 \\
Delta South & 141 & 71 & 50.4 \\
Total & 408 & 214 & 52.5 \\
\hline
\end{tabular}

214 (52.5\%) tested positive while 194 (47.5\%) tested negative for blood antibody test. The highest positive result for blood antibody test (55\%) was observed in males, while in female it constituted $51.4 \%$. The percentages of positive cases appear to be higher in males (55\%) compared to the females (51.4\%). However, the difference was not statistically significant $(p=0.962)$. The highest positive 
result was found in the age group of $\geq 60 \mathrm{yrs}$, which indicated $63.6 \%$ seropositivity (Table 3). This was followed by seropositivity in age groups 18 - 39 years (52.9\%) and 40 - 59 years $(45.3 \%)$. No significant difference $(\mathrm{p}=0.185)$ was observed in the prevalence of infection among the different age groups. Table 4 indicated that the highest prevalence rate for $H$. pylori was observed in Delta Central (61.7\%), followed by Delta North (50.4\%), while Delta South had the least percentage of $H$. pylori seropositivity (46.0\%). The seropositivity observed in Delta Central varied with Delta South $(\mathrm{p}=0.01)$, but not with Delta North $(\mathrm{p}$ $=0.06)$.

The univariate analysis and multivariate logistic regression analysis for the association between characteristics of participants and $H$. pylori status are shown in Table 5. In the univariate analysis, demographic characteristics such as age $(\mathrm{p}=0.330)$ and gender $(\mathrm{p}=0.506)$ were not associated with $H$. pylori status. Geographical region had a statistically significant association $(\mathrm{p}=0.031)$ with $H$. pylori status. Multivariate logistic regression further indicated that participants aged $\geq 65$ years were not at greater risk of $H$. pylori infection compared with those aged $18-39$ yrs $(O R=0.64 ; \mathrm{p}=0.382)$ or those aged $40-59$ yrs $(\mathrm{OR}=$ $0.47 ; \mathrm{p}=0.206)$. Similarly, females did not indicate significantly $(\mathrm{p}=0.516)$ greater risk for $H$. pylori seropositivity compared to the males. Participants from Delta Central were at greater risk $(\mathrm{OR}=1.89 ; \mathrm{p}=0.014)$ of $H$. pylori infection compared with those from Delta South. On the other hand, participants from Delta North were not at greater risk of infection compared with those from Delta South $(\mathrm{p}=0.476)$.

\section{Discussion}

Serologic testing represents a good primary screening test used in epidemiologic

Table 5. Univariate analysis and multivariate logistic regression test indicating association and risk of age, sex and geographical regions of participants with $H$. pylori.

\begin{tabular}{|c|c|c|c|c|c|c|}
\hline \multirow[b]{2}{*}{ Risk Factors } & \multicolumn{2}{|c|}{ H. pylori $(\mathrm{n}=408)$} & \multirow{2}{*}{$\begin{array}{c}\text { Univariate } \\
\text { Analysis } \\
\text { P-value }\end{array}$} & \multicolumn{3}{|c|}{ Multivariate Analysis } \\
\hline & $\begin{array}{c}\text { Present } \\
\mathrm{n}(\%)\end{array}$ & $\begin{array}{c}\text { Absent } \\
\text { n (\%) }\end{array}$ & & Odds Ratio (OR) & $\begin{array}{l}\text { 95\% Confidence } \\
\text { Intervals }(\mathrm{CI})\end{array}$ & P-value \\
\hline \multicolumn{7}{|l|}{ AGE } \\
\hline $18-39$ & $176(52.9)$ & $157(47.1)$ & 0.330 & 0.64 & $0.24-1.68$ & 0.382 \\
\hline $40-59$ & $24(45.3)$ & $29(54.7)$ & & 0.47 & $0.15-1.46$ & 0.206 \\
\hline$\geq 60^{*}$ & $14(63.4)$ & $8(36.4)$ & & 1 & & \\
\hline \multicolumn{7}{|l|}{ SEX } \\
\hline Males* & $66(55.0)$ & $54(45.0)$ & 0.506 & 1 & & \\
\hline Females & $148(51.4)$ & $140(48.6)$ & & 0.87 & $0.55-1.35$ & 0.516 \\
\hline \multicolumn{7}{|c|}{ Geographical Area } \\
\hline Delta South* & $64(46.0)$ & $75(54.0)$ & 0.031 & 1 & & \\
\hline Delta North & $71(50.4)$ & $70(49.6)$ & & 1.19 & $0.72-1.95$ & 0.476 \\
\hline Delta Central & $79(61.7)$ & $49(38.3)$ & & 1.89 & $1.12-3.17$ & 0.014 \\
\hline
\end{tabular}

${ }^{*}$ Reference group. 
studies for the evaluation of $H$ pylori status in patients not immediately requiring esophagogastroduodenal endoscopic studies [24]. It is relatively inexpensive, convenient and enables large numbers of subjects to be screened quickly. However the major limitations include the difficulty in defining the cutoff value that divides positive from negative subjects; its sensitivity to changes in reagents and laboratory conditions; its ability to detect and return false negative results up to 60 days after infection and remain positive for a considerable time after eradication [25]. These therefore call for appropriate equipment and techniques and validation of methods for each region, population and age. In this study we used and evaluated the performance of two different commercial serological test methods for the detection of immunoglobulin G (IgG) antibody to H. pylori. Our data revealed that antibodies were detected in $52.5 \%(\mathrm{n}=214)$ of the 408 volunteers who participated in the study, by using qualitative (Combo rapid kits) and 48.3\% ( $\mathrm{n}=197$ ) by using quantitative (Accu-Bind ELISA kits) serological test methods. Seventeen (17) of the 214 seropositive samples (tested by qualitative test method) gave negative results when tested by the quantitative ELISA test method. This shows that the qualitative test method is more sensitive than the quantitative method in detecting $H$. pylori antibodies.

The present finding based on the qualitative serology test therefore shows that the overall seroprevalence of $H$. pylori among asymptomatic adults aged 18 - 87 years is $52.5 \%$. This result is in contrast with previous studies conducted in Nigeria, which showed prevalence of $12.7 \%, 38.3 \%, 89.7 \%$ and $64 \%$ in Warri, Ethiope, Agbor, and Ibadan respectively [26] [27] [28] [29], but in agreement with a previous study in Sokoto Nigeria, which showed prevalence of 54.8\% [30]. Compared with results from other countries, our finding is in agreement with a study in Hong Kong, which reported seroprevalence of 58\% in healthy adult volunteers [31]. In contrast, H. pylori prevalence in this study was lower than those obtained in healthy adult populations of some countries such as China (80\%), Korea (75\%) [31] [32], but higher than other findings found in Netherlands (27\%), Australia (23\%) and United Kingdom (41\%) [33] [34] [35]. It is usually difficult to compare directly the prevalence rates from different studies due to variations in age and type of population. Nevertheless, the seroprevalence variations observed between our study and others may be attributed to differences in methodology and technical factors, variations in age, ethnicity as well as level of sanitation and social economic status of individual subjects screened.

In this study, the prevalence of $H$. pylori infection appeared higher in males $55 \%$ than females $51.4 \%$, but the difference was not statistically significant. This finding is in agreement with previous studies [27] [30]. In contrast, another study [26] indicated higher prevalence of $H$. pylori in females compared with males, while Kaore et al. [36] reported higher prevalence in male gender. Age distribution of $H$. pylori infection showed a trend towards decrease in infection with age from young $(52.9 \%)$ to middle-aged $(45.3 \%)$, then rises in the elderly (63.6\%). However, there was no statistically significant difference in $H$. pylori 
prevalence among age groups. This was consistent with a previous study by Dooley et al. [37]. In contrast, significant difference in $H$. pylori infection has been observed in age [38]. Studies conducted in the past decade have reported a high prevalence of $H$. pylori infection within the oldest population [39] [40]. However, a marked reduction in the prevalence of infection is previously reported in elderly people [41] [42]. The higher prevalence in the elderly may be explained by the mode of transmission of $H$. pylori (oro-fecal or oro-oral), taking into account the living and sanitary conditions of the elderly who are often neglected and uncared for due to high rate of poverty in developing countries. H. pylori prevalence rates are reported to vary widely between different geographical regions and ethnic groups [43]. Our finding which showed geographical variation between Delta Central and Delta South is in agreement with a previous study by Dorji et al. [44].

Our finding showed that $H$. pylori infection was associated with geographical region, but not with age and sex. The geographical areas or residences of participants were categorized into three senatorial zones of Delta state, Nigeria. Participants from Delta Central were at greater risk of $H$. pylori infection compared with those from Delta South. The reason behind this geographical variation is not known. However, it is thought that the risk of $H$. pylori prevalence by geographical areas may reflect differences in social and/or hygiene factors [45] and also related to differences in cultural background, social, dietary and environmental factors [46] [47]. A previous study [48] has also shown no relationship between $H$. pylori and gender, age in adults. In contrast, another study, [49] reported association between $H$. pylori infection and age and sex.

\section{Conclusion}

In conclusion the present study indicated an intermediate seroprevalence (52.5\%) of $H$. pylori among asymptomatic adults in Delta state, Nigeria. The prevalence of $H$. pylori infection was linked to geographical regions but not with sex and age.

\section{Acknowledgements}

We acknowledge the Ministry of Health, Delta State for ethical approval, and the participants within the three Senatorial districts of Delta state.

\section{Funding}

The research was privately funded. No grant or sponsorship from anywhere.

\section{References}

[1] Sethi, M.A, Chaudhuri, C., Len, K.C. and Hopman, W. (2013) Prevalence of Helicobacter pylori in a First Nations Population in Northwestern Ontario. Canadian Family Physician, 59, e182-187.

[2] Hunt, R.H., Chair, Xiao, S.D., Megraud, F., Leon-Barua, R. and Bazzoli, F. (2011) 
Helicobacter pylori in Developing Countries. Journal of Clinical Gastroenterology, 45, 383-388. https://doi.org/10.1097/MCG.0b013e31820fb8f6

[3] Akin, O.Y., Tsou, V.M. and Werner, A.L. (1995) Gastrospirillum Hominis-Associated Chronic Active Gastritis. Pediatric Pathology \& Laboratory Medicine, 15, 429- 435. https://doi.org/10.3109/15513819509026978

[4] Akada, J.K., Shirai, M., Takeuchi, H.T., suda, M. and Nakazawa, T. (2000) Identification of the Urease Operon in Helicobacter pylori and Its Control by mRNA Decay in Response to pH. Molecular Microbiology, 36, 1071-1084. https://doi.org/10.1046/j.1365-2958.2000.01918.x

[5] Akhiani, A.A., Pappo, J., Kabok, Z., Schon, K., Gao, W., Franzen, L.E. and Lycke, N. (2002) Protection against Helicobacter pylori Infection Following Immunization Is IL-12-Dependent and Mediated by Th1 Cells. Journal of Immunology, 169, 6977-6984. https://doi.org/10.4049/jimmunol.169.12.6977

[6] Martin, D., May, S., Tweedle, D., Hollanders, D., Ravenscroft, M. and Miller, J. (1981) Differences in Relapse Rates of Duodenal Ulcer after Healing with Cimetidine or Tripotassium Dicitrato Bismuthate. Lancet, 1, 7-10. https://doi.org/10.1016/S0140-6736(81)90114-8

[7] Nomura, A., Stemmermann, G.N., Chyou, P.H., Perez-Perez, G.I. and Blaser, M.J. (1994) Helicobacter pylori Infection and Risk of Duodenal and Gastric Ulceration. Annal of Internal Medicine, 120, 977-981. https://doi.org/10.7326/0003-4819-120-12-199406150-00001

[8] Tursi, A.I., Cammarota, G., Papa, A., Cuoco, L., Gentiloni, N., Fedeli, P., Fedeli, G. and Gasbarrini, G. (1997) The Modes of Transmission of Helicobacter pylori Infection. Recenti Progressi in Medicina, 88, 232-336.

[9] Malaty, H.M. and Graham, D.Y. (1994) Importance of Childhood Socioeconomic Status on the Current Prevalence of Helicobacter pylori Infection, Gut, 35, 742-751. https://doi.org/10.1136/gut.35.6.742

[10] Mendall, M.A., Goggin, P.M., Molineaux, N., et al. (1992) Childhood Living Conditions and Helicobacter pylori Seropositivity in Adult Life, Lancet, 339, 896-897. https://doi.org/10.1016/0140-6736(92)90931-R

[11] Novis, B.H., Gabay, G. and Naftali, T. (1998) Helicobacter pylori: The Middle East Scenario. The Yale Journal of Biology and Medicine, 71, 135-141.

[12] Li, Y.H., Guo, H., Zhang, P.B., Zhao, X.Y. and Da, S.P. (2004) Clinical Value of Helicobacter pylori Stool Antigen Test, ImmunoCard STAT HpSA, for Detecting $\mathrm{H}$ Pylori Infection. World Journal of Gastroenterology, 10, 913-914.

[13] Miranda, A.C.P., Machado, R.S., da Silva, E.M.K. and Kawakami, E. (2010) Seroprevalence of Helicobacter pylori Infection among Children of Low Socioeconomic Level in São Paulo. Sao Paulo Medical Journal, 128, 187-191. https://doi.org/10.1590/S1516-31802010000400002

[14] Malaty, H.M. (2007) Epidemiology of Helicobacter pylori Infection. Best Practice \& Research Clinical Gastroenterology, 21, 205-214.

[15] Genta, R.M. (2002) Review Article: After Gastritis-An Imaginary Journey into a Helicobacter-Free World. Alimentary Pharmacology \& Therapeutics, 16, 89. https://doi.org/10.1046/j.1365-2036.16.s4.15.x

[16] Oliveira, A.M., Queiroz, D.M., Rocha, G.A. and Mendes, E.N. (1994) Seroprevalence of Helicobacter pylori Infection in Children of Low Socioeconomic Level in Belollorizonte, Brazil. The American Journal of Gastroenterology, 89, 2201-2204.

[17] Rehnberg-Laiho, L., Rautelin, H., Koskela, P., Sarna, S., Pukkala, E., Aromaa, A., 
Knekt, P. and Kosunen, T.U. (2001) Decreasing Prevalence of Helicobacter Antibodies in Finland, with Reference to the Decreasing Incidence of Gastric Cancer. Epidemiology \& Infection, 126, 37-42.

[18] Roosendaal, R., Kuipers, E.J., Buitenwerf, J., VanUffelen, C., Meuwissen, S.G., Van Kamp, G.J. and Vandenbroucke-Grauls, C.M. (1997) Helicobacter pylori and the Birth Cohort Effect: Evidence of a Continuous Decrease of Infection Rates in Childhood. America Journal Gastroenterology, 92, 1480-1482.

[19] Ndububa, D.A., Agbakwuru, A.E., Adebayo, R.A., et al. (2001) Upper Gastrointestinal Findings and Incidence of Helicobacter pylori Infection among Nigeria Patients with Dyspepsia. West Africa Journal of Medicine, 20, 140-145.

[20] Fischbach, W., Malfertheiner, P., Hoffmann, J.C., Bolten, W., Kist, M. and Koletzko, S. (2009) Helicobacter pylori and Gastroduodenal Ulcer Disease. Deutsches Ärzteblatt International, 106, 801-808.

[21] Tijjani, B. and Umar, A. (2008) Peptic Ulcer Disease and Helicobacter pylori Infection at Kano, Nigeria. International Journal of Gastroenterology, 8, 1.

[22] Pronovost, A.D., Rose, S.L., Pawlak, J.W., Robin, H. and Schneider, R. (1994) Evaluation of a New Immunodiagnostic Assay for Helicobacter pylori Antibody Detection: Correlation with Histopathological and Micro-Biological Results. Journal of Clinical Microbiology, 32, 46-50.

[23] Vans, D.J., Evans, D.G., et al. (1989) A Sensitive and Specific Seriologic Test for Detection of Campylobacter Pylori Infection. Gastroenerology, 96, 1004.

[24] Kimmel, B., Bosserhoff, A. and Frank, R. (2000) Identification of Immunodominant Antigens from Helicobacter pylori and Evaluation of Their Reactivities with Sera from Patients with Different Gastroduodenal Pathology. Infection and Immunity, 68, 915-920. https://doi.org/10.1128/IAI.68.2.915-920.2000

[25] Brown, L.M. (2000) Helicobacter pylori: Epidemiology and Routes of Transmission. Epidemiologic Reviews, 22, 284-297.

https://doi.org/10.1093/oxfordjournals.epirev.a018040

[26] Jemikajah, D.J. and Okogun, G.R.A. (2014) Health Point: Prevalence of Helicobacter pylori in Central Hospital, Warri, Nigeria. African Journal of Cellular Pathology, 3, 57-60.

[27] Alo, M.N., Alhassan, H.M., Saidu, A.Y., Ugah, U.I. And Anyim, C. (2013) The Prevalence of Helicobacter pylori Infection in Asymptomatic Persons in Ethiope East Local Government Area of Delta State, Nigeria. International Journal of Public Health Pharmapeutic, 1, 115-119.

[28] Onemu, S.O., Ophori, E.A., Isibor, C. and Johnny, E.J. (2011) Immunological Response to Helicobacter pylori among Healthy Volunteers in Agbor, Nigeria. Asian Pacific Journal of Tropical Disease, 1, 38-40.

[29] Jemilohun, A.C., Otegbayo, J.A., Ola, S.O., Oluwasola, O.A. and Akere, A. (2011) Prevalence of Helicobacter pylori among Nigerian Patients with Dyspepsia in Ibadan. Pan African Medical Journal, 6, 18. https://doi.org/10.4314/pamj.v6i1.69090

[30] Saidu, A.Y., Munir, G., Salihu, Y.N., Sani, M., Muhammad, Y. and Dodo, A.M. (2015) Seroprevalence of Helicobacter pylori among Adult in Sokoto Metropolis. IOSR Journal of Nursing and Health Science, 4, 64-69.

[31] Wong, B.C., Lam, S.K., Ching, C.K., et al. (1999) Differential Helicobacter pylori Infection Rates in Two Contrasting Gastric Cancer Risk Regions of South China. China Gastric Cancer Study Group. Journal of Gastroenterology and Hepatology, 14, 120-125. https://doi.org/10.1046/j.1440-1746.1999.01823.x 
[32] Malaty, H.M., Kim, J.G., Kim, S.D., et al. (1996) Prevalence of Helicobacter pylori Infection in Korean Children: Inverse Relation to Socioeconomic Status Despite a Uniformly High Prevalence in Adults. American Journal of Epidemiology, 143, 257-262. https://doi.org/10.1093/oxfordjournals.aje.a008736

[33] Bohmer, C.J., Klinkenberg-Knol, E.C., Kuipers, E.J., et al. (1997) The Prevalence of Helicobacter pylori Infection among Inhabitants and Healthy Employees of Institutes for the Intellectually Disabled. The American Journal of Gastroenterology, 92, 1000-1004.

[34] Lambert, J.R., Lin, S.K., Sievert, W., et al. (1995) High Prevalence of Helicobacter pylori Antibodies in an Institutionalized Population: Evidence for Person-to-Person Transmission. The American Journal of Gastroenterology, 90, 2167-2171.

[35] Harris, A.W., Douds, A., Meurisse, E.V., et al. (1995) Seroprevalence of Helicobacter pylori in Residents of a Hospital for People with Severe Learning Difficulties. European Journal of Gastroenterology \& Hepatology, 7, 21-23.

[36] Kaore, N.M., Nagdeo, N.V. and Thombare, V.R. (2012) Comparative Evaluation of the Diagnostic Tests for Helicobacter pylori and Dietary Influence for Its Acquisition in Dyspeptic Patients: A Rural Hospital Based Study in Central India. JCDR, No. 6, 636-641.

[37] Dooley, C.P., Cohen, H., Fitzgibbons, P.L., Bauer, M., Appleman, M.D., Perez-Perez, G.I. and Blaser, M.J. (1989) Prevalence of Helicobacter pylori Infection and Histologic Gastritis in Asymptomatic Persons. The New England Journal of Medicine, 321, 1562-1566. https://doi.org/10.1056/NEJM198912073212302

[38] Zhu, Y., Zhou, X., Wu, J., Su, J. and Zhang, G. (2014) Risk Factors and Prevalence of Helicobacter pylori Infection in Persistent High Incidence Area of Gastric Carcinoma in Yangzhong City. Gastroenterology Research and Practice, 2014, Article ID: 481365. https://doi.org/10.1155/2014/481365

[39] Regev, A., Fraser, G.M., Braun, M., Maoz, E., Leibovici, L. and Niv, Y. (1999) Seroprevalence of Helicobacter pylori and Length of Stay in a Nursing Home. Helicobacter, 4, 89-93. https://doi.org/10.1046/j.1523-5378.1999.98640.x

[40] Pilotto, A., Fabrello, R., Franceschi, M., Scagnelli, M., Soffiati, F., Di Mario, F., Fortunato, A. and Valerio, G. (1996) Helicobacter pylori Infection in Asymptomatic Elderly Subjects Living at Home or in a Nursing Home: Effects on Gastric Function and Nutritional Status. Age Ageing, 25, 245-249.

https://doi.org/10.1093/ageing/25.3.245

[41] Neri, M.C., Lai, L., Bonetti, P., Baldassarri, A.R., Monti, M., De Luca, P., Cunietti, E. and Quatrini, M. (1996) Prevalence of Helicobacter pylori Infection in Elderly Inpatients and in Institutionalized Old People: Correlation with Nutritional Status. Age Ageing, 25, 17-21. https://doi.org/10.1093/ageing/25.1.17

[42] Salles-Montaudon, N., Dertheil, S., Broutet, N., Gras, N., Monteiro, L., De Mascarel, A., Megraud, F. and Emeriau, J.P. (2002) Detecting Helicobacter pylori Infection in Hospitalized Frail Older Patients: The Challenge. Journal of the American Geriatrics Society, 50, 1674-1680. https://doi.org/10.1046/j.1532-5415.2002.50459.x

[43] Goh, K.L., Chan, W.K., Shiota, S. and Yamaoka, Y. (2011) Epidemiology of Helicobacter pylori Infection and Public Health Implications. Helicobacter, 16, 1-9. https://doi.org/10.1111/j.1523-5378.2011.00874.x

[44] Dorji, D., Dendup, T., Malaty, H.M., Wangchuk, K., Yangzom, D. and Richter, J.M. (2014) Epidemiology of Helicobacter pylori in Bhutan: The Role of Environment and Geographic Location. Helicobacter, 19, 69-73. https://doi.org/10.1111/hel.12088 
[45] Malaty, H.M., Graham, D.Y., Wattigney, W.A., et al. (1999) Natural History of Helicobacter pylori Infection in Childhood: 12-Year Follow-Up Cohort Study in a Biracial Community. Clinical Infectious Diseases, 28, 279-282. https://doi.org/10.1086/515105

[46] Graham, D.Y., Malaty, H.M., Evans, D.G., Evans, D.J., Klein, P.D. and Adam, E. (1991) Epidemiology of Helicobacter pylori in an Asymptomatic Population in the United States: Effect of Age, Race and Socioeconomic Status. Gastroenterology, 100, 1495-1501.

[47] Mitchell, H.M., Li, Y.Y., Hu, P.J., Liu, Q., Chen, M., Du, G.G., et al. (1992) Epidemiology of Helicobacter pylori in Southern China: Identification of Early Childhood as the Critical Period for Acquisition. The Journal of Infectious Diseases, 166, 149-153. https://doi.org/10.1093/infdis/166.1.149

[48] Shi, R., Xu, S. and Zhang, H. (2008) Prevalence and Risk Factors for Helicobacter pylori Infection in Chinese Populations. Helicobacter, 13, 157-165. https://doi.org/10.1111/j.1523-5378.2008.00586.x

[49] Malcolm, C.A., MacKay, W.G., Shepherd, A. and Weaver, L.T. (2004) Helicobacter pylori in Children Is Strongly Associated with Poverty. Scottish Medical Journal, 49, 136-138. https://doi.org/10.1177/003693300404900406

Submit or recommend next manuscript to SCIRP and we will provide best service for you:

Accepting pre-submission inquiries through Email, Facebook, LinkedIn, Twitter, etc. A wide selection of journals (inclusive of 9 subjects, more than 200 journals) Providing 24-hour high-quality service User-friendly online submission system Fair and swift peer-review system Efficient typesetting and proofreading procedure Display of the result of downloads and visits, as well as the number of cited articles Maximum dissemination of your research work

Submit your manuscript at: http://papersubmission.scirp.org/ Or contact aim@scirp.org 